\title{
Early pregnancy diagnosis in the ewe, based on milk progesterone levels
}

\author{
M. Shemesh, N. Ayalon* and T. Mazor \\ Departments of Hormone Research and ${ }^{*}$ Reproduction, Kimron Veterinary Institute, \\ Beit Dagan, Israel
}

\begin{abstract}
Summary. Plasma and milk progesterone concentrations in pregnant sheep (18-22 days after mating) were similar, about $3.7 \mathrm{ng} / \mathrm{ml}$ whereas values in non-pregnant sheep were $<1 \mathrm{ng} / \mathrm{ml}$. Lambing results indicated identical accuracy for both methods ( 82 and $84 \%$ in 2 flocks). The accuracy was $92-100 \%$ for ewes diagnosed nonpregnant in the breeding season, but for ewes tested in the non-breeding season the diagnosis of non-pregnancy according to milk progesterone levels was only $50 \%$ accurate.
\end{abstract}

\section{Introduction}

A striking difference in peripheral plasma progesterone levels between pregnant and nonpregnant cows can be observed by 19 days after insemination (Shemesh, Ayalon \& Lindner, 1968) and it was suggested that this difference might furnish the basis for an early pregnancy test. Encouraging results of pregnancy testing in sheep, based upon plasma progesterone values at fixed times after breeding, have since been reported by Bassett, Oxborrow, Smith \& Thorburn (1969), Robertson \& Sarda (1971), and Shemesh, Ayalon \& Lindner (1973). The discovery that the levels of progesterone in the milk of cows parallel the concentrations of this hormone in blood (Laing \& Heap, 1971) has led to a number of reports concerning the use of milk progesterone levels as a diagnostic method for the determination of pregnancy in dairy cows. However, no work has been reported on the use of milk progesterone levels as a means of early pregnancy diagnosis in the ewe.

The present communication describes our experience with the early pregnancy test based upon a rapid radioimmunoassay for both plasma and milk progesterone in fat-tailed milking sheep in Israel.

\section{Materials and Methods}

\section{Animals}

Ewes were examined for pregnancy during either (a) the normal breeding season, or (b) the anoestrous period. In the breeding season, 2 flocks of Awassi sheep, containing 34 and 173 ewes, were investigated during the months of July and August, which is the main breeding period for this breed. The ewes were lactating and testing for oestrus was performed twice daily by using aproned teaser rams, under the observation of experienced shepherds. Ewes in oestrus were hand-mated twice at $12 \mathrm{~h}$ intervals with fertile rams. In the anoestrous period, samples were taken from 72 Awassi ewes, including both lactating and non-lactating sheep, during the middle of the anoestrous period in April.

Jugular blood samples $(5 \mathrm{ml})$ were collected onto heparin while $10 \mathrm{ml}$ samples of fore-milk were collected into plastic vials with potassium dichromate as a preservative. During the breeding season samples were collected 18-22 days after mating. During the anoestrous period 
breeding dates were unknown. However, since it has been shown that at this time plasma progesterone levels are basal in non-pregnant ewes (Rawlings, Kennedy, Chang, Hill \& Henricks, 1977; Walton, McNeilly, McNeilly \& Cunningham, 1977) it was reasoned that low plasma or milk progesterone values would clearly indicate non-pregnancy.

\section{Progesterone assay}

The progesterone content in unextracted fore-milk and plasma samples was determined by radioimmunoassay (RIA) using an antibody raised in our laboratory in rabbit against progesterone-11 $\alpha$-hemisuccinate-BSA. This antibody showed less than $0.01 \%$ cross-reaction with cortisol, corticosterone. cholesterol, 17 $\alpha$-hydroxyprogesterone, oestrone, oestradiol, testosterone, androstenedione, prostaglandins $\mathrm{E}$ and F. The RIA was carried out with $0.05 \mathrm{ml}$ samples of unextracted milk and $0.1 \mathrm{ml}$ plasma. The RIA technique was essentially as described by Shemesh \& Hansel (1975). Separation of free from antibody-bound progesterone was accomplished with dextran-coated charcoal. For purposes of comparison, milk and blood plasma levels of progesterone were determined by the same RIA technique in 34 samples collected from the same ewes at 18-22 days after mating.

Known amounts of progesterone, equivalent to 2,3 and $4 \mathrm{ng} / \mathrm{ml}$, were added to plasma containing $0.3 \mathrm{ng}$ progesterone $/ \mathrm{ml}$ and to milk containing $0.5 \mathrm{ng}$ progesterone $/ \mathrm{ml}$. The recovery of progesterone was $94 \pm 4 \%(n=20)$ from plasma and $55 \pm 4 \%(n=40)$ from milk. The intraassay coefficient of variation between duplicate pairs was $8.5 \%$ for $0.5 \mathrm{ng} / \mathrm{ml}$ ( 15 replicates), 2.0 $\mathrm{ng} / \mathrm{ml}$ ( 20 replicates), and 3 and $4 \mathrm{ng} / \mathrm{ml}$ (10 replicates of each). The inter-assay coefficient of variation was $11.2 \%$ for an internal standard at 0.5 and $2.0 \mathrm{ng} / \mathrm{ml}(32$ replicates of each). The results obtained were corrected by multiplying the milk values determined by $100 / 55$. The calibration curve was fitted by computer according to the method of Rodbard \& Lewald (1970). The lower limit of sensitivity was $0.2 \mathrm{ng} / \mathrm{ml}$.

On the basis of preliminary studies, values above $1.5 \mathrm{ng}$ progesterone/ml milk were considered as positive for pregnancy. These results were compared with lambing data.

\section{Results}

The results for ewes examined in the breeding season are shown in Table 1. The plasma progesterone levels were not significantly different from those found in milk, and values in the non-pregnant ewes were very low.

The accuracy of the pregnancy diagnosis by milk progesterone determination was evaluated in the 2 flocks as shown in Table 2.

Identical levels of accuracy were found when results of milk and blood progesterone determinations for the same ewes $(n=34)$ were compared.

Table 1. Progesterone concentrations (mean \pm s.e.m., range in parentheses) in unextracted fore-milk and jugular plasma in pregnant and non-pregnant ewes during the breeding season

\begin{tabular}{lccccc}
\hline & \multicolumn{2}{c}{ Fore-milk } & & \multicolumn{2}{c}{ Jugular plasma } \\
\cline { 2 - 3 } & Pregnant & Not pregnant & & Pregnant & Not pregnant \\
\hline $\begin{array}{c}\text { No. of ewes } \\
\begin{array}{c}\text { Days after } \\
\text { mating }\end{array}\end{array}$ & 128 & 79 & & 28 & 6 \\
$(18-22)$ & $\begin{array}{l}3.5 \pm 0.4 \\
(1.5-6.5)\end{array}$ & N.D.-1.0 & & $\begin{array}{l}3.8 \pm 0.5 \\
(1.5-4.5)\end{array}$ & N.D.-1.0 \\
\hline
\end{tabular}

N.D., not detectable. 
Table 2. Accuracy, according to lambing results, of pregnancy diagnosis by milk and plasma progesterone determinations $18-22$ days after mating during the breeding season

\begin{tabular}{|c|c|c|c|c|c|}
\hline \multirow[b]{2}{*}{ Flock } & \multirow[b]{2}{*}{$\begin{array}{l}\text { No. of } \\
\text { ewes }\end{array}$} & \multicolumn{2}{|c|}{ Milk } & \multicolumn{2}{|c|}{ Plasma } \\
\hline & & $\begin{array}{c}\text { Diagnosed } \\
\text { pregnant }\end{array}$ & $\begin{array}{c}\text { Diagnosed } \\
\text { non-pregnant }\end{array}$ & $\begin{array}{c}\text { Diagnosed } \\
\text { pregnant }\end{array}$ & $\begin{array}{c}\text { Diagnosed } \\
\text { non-pregnant }\end{array}$ \\
\hline 1 & 34 & $\begin{array}{l}23 / 28 \\
(82 \%)\end{array}$ & $\begin{array}{c}6 / 6 \\
(100 \%)\end{array}$ & $\begin{array}{l}23 / 28 \\
(82 \%)\end{array}$ & $\begin{array}{c}6 / 6 \\
(100 \%)\end{array}$ \\
\hline 2 & 173 & $\begin{array}{c}84 / 100 \\
(84 \%)\end{array}$ & $\begin{array}{l}67 / 73 \\
(92 \%)\end{array}$ & & \\
\hline
\end{tabular}

Table 3. Accuracy of pregnancy diagnosis during the anoestrous season

\begin{tabular}{lccccc}
\hline & \multicolumn{2}{c}{ Milk } & & \multicolumn{2}{c}{ Plasma } \\
\cline { 2 - 3 } \cline { 5 - 6 } $\begin{array}{c}\text { Type of } \\
\text { ewe }\end{array}$ & $\begin{array}{c}\text { Diagnosed } \\
\text { pregnant }\end{array}$ & $\begin{array}{c}\text { Diagnosed } \\
\text { non-pregnant }\end{array}$ & & $\begin{array}{c}\text { Diagnosed } \\
\text { pregnant }\end{array}$ & $\begin{array}{c}\text { Diagnosed } \\
\text { non-pregnant }\end{array}$ \\
\hline Non-lactating & - & - & & $22 / 24$ & $12 / 13$ \\
& $6 / 6$ & $15 / 30$ & & $(92 \%)$ & $(92 \%)$ \\
Lactating & $(100 \%)$ & $(50 \%)$ & - & - \\
\hline
\end{tabular}

Table 3 shows the accuracy of pregnancy diagnosis performed during the anoestrous season. It is apparent that accuracy was quite low for diagnosing non-pregnancy in lactating ewes, when using milk during the anoestrous period.

\section{Discussion}

The very similar values of progesterone concentration in milk and plasma found in this study could be explained by the fact that a highly specific antiserum was used which results in minimal cross-reaction with other metabolites. The low percentage of recovered progesterone $(55 \pm 4 \%)$ in the milk might be due to the presence of a protein, such as transcortin, which binds progesterone, thus affecting the recovery rate.

Similar results were found in both flocks (Table 2) regarding the accuracy of pregnancy diagnosis based upon milk progesterone levels. In Flock 1 the same 5 ewes were erroneously diagnosed as pregnant according to their milk and plasma progesterone concentrations. However, the accuracy of these tests in ewes without known breeding dates tested in April during the period of anoestrus was not very good. It has been shown that anoestrus in Awassi sheep is at its height during April and May (Amir, 1965). Since plasma progesterone levels are basal during the anoestrous season (Rawlings et al., 1977; Walton et al., 1977), it was expected that low plasma or milk progesterone values would clearly indicate non-pregnancy, but the results were clearly affected by lactation, being reasonably good for plasma values in non-lactating ewes but not for milk values of lactating animals. The abnormally low milk progesterone values found in such a high proportion of pregnant lactating ewes during anoestrus suggests the possible presence at this time of a higher level of a protein in the milk of the lactating ewe which binds progesterone and thus interferes with the assay. Plasma samples from the lactating ewes sampled during the anoestrous period were unfortunately lost and were unavailable for assay. However, in ongoing work during the anoestrous season this year, pregnancy diagnosis results, using plasma and milk from the same ewes, have shown similar discrepancies regarding lactating ewes as in the present report. Similar discrepancies in the accuracy of pregnancy tests in lactating and 
non-lactating ewes during anoestrus (with lowered accuracy in lactating ewes), have also been noted when pregnancy diagnosis was based on histological evaluation of biopsies of the vaginal epithelium (N. Ayalon, X. Eisenberg, Y. Lewis \& S. Marcus, unpublished results). These unexpected findings are being further investigated.

In conclusion, it would seem that for pregnancy diagnosis in lactating sheep, at least during the period of sexual activity, measuring progesterone levels in milk could be a convenient substitute for progesterone determination in blood.

We thank Dr S. Marcus and Dr A. Luft for providing most of the samples examined.

\section{References}

Amir, D. (1965) Fertility of Awassi ewes bred during different periods of the breeding season. Ktavim-Records of the Agricultural Research Station, State of Israel 15, 45-49.

Bassett, J.M., Oxborrow, T.J., Smith, I.D. \& Thorburn, G.D. (1969) The concentration of progesterone in the peripheral plasma of the pregnant ewes. $J$. Endocr. 45, 449-457.

Laing, J.A. \& Heap, R.B. (1971) The concentration of progesterone in the milk of cows during the reproductive cycle. Br. vet. J. 127, 19-22.

Rawlings, N.C., Kennedy, S.W., Chang, C.H., Hill, J.R., Jr \& Henricks, D.M. (1977) Onset of seasonal anestrus in the ewe. J. Anim. Sci. 44, 791-797.

Robertson, H.A. \& Sarda, I.R. (1971) A very early pregnancy test for mammals; its application to the cow, ewe and sow. J. Endocr. 49, 407-419.

Rodbard, D. \& Lewald, J.E. (1970) Computer analysis of radioligand assay and radioimmunoassay data. Acta endocr., Copenh., Suppl. 147, 79-103.
Shemesh, M. \& Hansel, W. (1975) Levels of prostaglandin $F(P G F)$ in bovine endometrium uterine venous ovarian arterial and jugular plasma during the estrous cycle. Proc. Soc. exp. Biol. Med. 148, 123-126.

Shemesh, M., Ayalon, N. \& Lindner, H.R. (1968) Early effect of conceptus on plasma progesterone level in the cow. J. Reprod. Fert. 15, 161-164.

Shemesh, M., Ayalon, N. \& Lindner, H.R. (1973) Early pregnancy diagnosis based upon plasma progesterone levels in the cow and ewe. J. Anim. Sci. 36, 726-729.

Walton, J.S., McNeilly, J.R., McNeilly, A.S. \& Cunningham, F.J. (1977) Changes in concentrations of follicle-stimulating hormone, luteinizing hormone, prolactin and progesterone in the plasma of ewes during the transition from anoestrus to breeding activity. J. Endocr. 75, 127-136.

Received 6 November 1978 